\title{
Differences in metabolism of three Conyza species to herbicides glyphosate and triclopyr revealed by LC-MS/MS
}

\author{
Christos Anagnostopoulos ${ }^{1}$, Panagiota Stasinopoulou ${ }^{2}$, Panagiotis Kanatas ${ }^{3}$, and Ilias Travlos ${ }^{2^{*}}$ \\ 'Benaki Phytopathological Institute, 8 St. Delta str., GR-145 61 Kifissia (Athens), Greece. \\ ${ }^{2}$ Agricultural University of Athens, 75, Iera Odos St., 11855 Athens, Greece. "Corresponding author (travlos@aua.gr). \\ ${ }^{3}$ Agricultural Cooperative of Mesolonghi-Nafpaktia, 30200 Mesolonghi, Greece.
}

Received: 20 October 2019; Accepted: 11 December 2019; doi:10.4067/S0718-58392020000100100

\begin{abstract}
Conyza spp. are among the most common weeds found in perennial crops, and resistance to several herbicides has already occurred worldwide. In the present study, pot and laboratory experiments were conducted to evaluate differences in glyphosate and triclopyr susceptibility between different biotypes of Conyza spp. Plant material was obtained from seeds collected in perennial crops in Greece. Seeds of four Conyza spp. biotypes were sown in separate pots and treated with glyphosate at the rosette stage, while seeds of six different Conyza spp. biotypes were sown and treated with triclopyr. Twenty-four hours after the herbicide treatment, the aboveground part of the weeds was manually collected and plant samples were prepared to determine the analytes with LC-MS/MS. In two C. bonariensis biotypes, the glyphosate concentration was $50 \%$ to $52 \%$ lower than for other biotypes; therefore, they could be considered as potentially resistant to glyphosate because the resistant biotype had a stronger and faster metabolism than the sensitive biotype, transforming glyphosate into non-toxic metabolites. The higher glyphosate concentration was detected in C.canadensis biotypes, which proved to be potentially susceptible to glyphosate. Three $C$. bonariensis biotypes and one $C$. albida biotype were less susceptible to triclopyr because analytes were detected in $63 \%$ to $82 \%$ higher concentrations than the two C. canadensis biotypesthat were susceptible to triclopyr. These results reveal significant differences between the three species, confirm the problem of herbicide resistance, and suggest that glyphosate and triclopyr efficacy in Conyza spp. is merely due to herbicide metabolism to other compounds.
\end{abstract}

Key words: Conyza spp., glyphosate, herbicide resistance, LC-MS/MS, triclopyr.

\section{INTRODUCTION}

Different species of the genus Conyza are found in Europe that were introduced as neophytes from both North and South America. These invasive species are now considered to be among the most common plant species in the recipient territory. Conyza plants occur as weeds in more than 40 crops in 70 countries worldwide (Holm et al., 1997). Conyza bonariensis, C. canadensis, and C.albida (or C. sumatrensis) are the three main species of Conyza commonly found in perennial crops. Conyza bonariensis and $C$. canadensis are the most common and abundant of the three species, while $C$. albida was more recently introduced (Travlos and Chachalis, 2010). Conyza weed plants are considered highly adaptable, extremely competitive, and easily dispersed; they are particularly successful in extending herbicide resistance. They are often characterized by several ecological properties such as prolific seed formation, wide range of pollinating insects or self-fertilization, ability to outcross, short period from flowering to production of viable seed, non-specific habitat requirements, ease and distance of seed dispersal, long germination period, and low dormancy and viability in the soil for 
several years (Hao et al., 2009).There are currently many reports from farmers that Conyza spp. have become increasingly difficult to control with several herbicides, especially in no-tillage or minimum tillage systems (Urbano et al., 2007; Travlos et al., 2009; Travlos and Chachalis, 2013).

Glyphosate ( $N$-(phosphonomethyl)glycine) is a non-selective herbicide with little or no activity in the soil that acts as a potent inhibitor of 5-enolpyruvylshikimate-3-phosphate synthase (EPSPS; EC 2.5.1.19) by blocking the synthesis of major compounds in the shikimic acid pathway, thereby instigating ultrastructural atrophy and arresting protein synthesis (Nandula et al., 2007). Glyphosate has been used extensively on both agricultural and non-agricultural land for more than $35 \mathrm{yr}$ (Powles, 2008). No cases of resistant weeds were reported during the first years of use and the evolution of glyphosate resistance was considered unlikely (Bradshaw et al., 1997). To date, more than 30 weed species have reportedly developed resistance to glyphosate worldwide (Heap, 2019). Although its use in glyphosate-resistant crops has resulted in the evolution of weed resistance (Owen and Zelaya, 2005), cultivation of glyphosate-resistant crops cannot be considered as the only cause (Dill, 2005). Repeated use of glyphosate in no-tillage systems can greatly increase the risk of resistance, even in the absence of glyphosate-resistant crops (Neve et al., 2003; Travlos and Chachalis, 2010).

Triclopyr ([(3,5,6-trichloro-2-pyridinyl)oxy]acetic acid) is a pyridine-based herbicide used to control woody plants and annual and perennial broadleaf weeds. It is absorbed through the leaves or roots and is translocated primarily through the symplastic pathway and accumulates in the growing points of the plant (Radosevich and Bayer, 1979). Its mechanism of action is not fully understood, but it appears to involve cell wall plasticity and nucleic acid metabolism (Ahrens, 1994). Triclopyr can damage plants due to root uptake but does not work effectively in that way (Newton et al., 1990). Triclopyr acts as a synthetic auxin by giving the plant an auxin overdose of 1000 times its natural levels, which disrupts the hormonal balance and interferes with growth. No research of the reasons for the species selectivity of triclopyr has been undertaken. One of the studies using cell suspension of soybean cultures showed that triclopyr acid was easily absorbed and metabolized. The major metabolic products were the aspartate and glutamate conjugates of triclopyr, which were not released from the cells (Lewer and Owen, 1987).

There are several plausible herbicide resistance mechanisms for weeds, including herbicide absorption (De Prado et al., 2005) and reduced herbicide movement from the site of absorption to the target site due to vacuolar herbicide sequestration (Ge et al., 2010; Yu et al., 2010). Rapid metabolic detoxification of the herbicide (De Prado et al., 2005; Busi et al., 2011), herbicide target site alteration (Powles and Yu, 2010), and gene amplification (Gaines et al., 2010) are other mechanisms.

The present study was conducted to evaluate several Conyza spp. biotypes of in terms of their susceptibility to herbicides glyphosate and triclopyr. The specific objectives of this work were (a) to evaluate the different responses of three Conyza species to the herbicides glyphosate and triclopyr, and (b) to study the herbicide metabolism in $\mathrm{R}$ and $\mathrm{S}$ biotypes of Conyza spp. as a potential source of glyphosate and triclopyr resistance of this weed. The evaluation was performed in pot experiments and the analysis was performed by complex analytical techniques.

\section{MATERIALS AND METHODS}

\section{Pot experiments}

Conyza spp. seeds were collected from perennial crops in Greece. Seeds of four different biotypes of Conyza spp. (Conyza bonariensis [L.] Cronquist, C. canadensis [L.] Cronquist, C. albida Willd. ex Spreng., and C. sumatrensis (Retz.) E. Walker) were sown in separate pots to study weedsusceptibility to glyphosate (samples $3,4,9,10$ ), while seeds of six different biotypes of Conyza spp. were sown in separate pots to study triclopyr (samples 2, 3, 4, 7, 9, 10) (Table 1). Seeds were placed on the substrate surface and watered. When seedlings were at the rosette stage $(7$ to $9 \mathrm{~cm}$ diameter and 10 to 15 leaves), the abovementioned Conyza spp. biotypes were treated with the recommended rates of glyphosate and triclopyr ( $0.72 \mathrm{~kg}$ ai ha- ${ }^{-1}$ and $0.96 \mathrm{~kg}_{\text {ai ha-1 }}$, respectively), using a custom built, compressed-air, low-pressure flatfan nozzle experimental sprayer. Twenty-four hours after the herbicide treatment, the aboveground part of weeds was manually collected. The pot experiment was carried out and repeated in the field at the Agricultural University of Athens in the summer of 2016. The experiment had a completely randomized design with a split-plot arrangement, and biotypes were the main plots and herbicide treatments were the subplots. There was also an untreated control in which no herbicide was applied. Each pot was an independent sample. 
Table 1. Biotypes sprayed with maximum recommended rates of glyphosate and triclopyr.

\begin{tabular}{lcc}
\hline Code & Biotypes & Treatment \\
\hline Sample 2 & Conyza bonariensis & Triclopyr \\
Sample 3 & C. bonariensis & Glyphosate, Triclopyr \\
Sample 4 & C. bonariensis & Glyphosate, Triclopyr \\
Sample 7 & C. albida & Triclopyr \\
Sample 9 & C. canadensis & Glyphosate, Triclopyr \\
Sample10 & C. canadensis & Glyphosate, Triclopyr \\
\hline
\end{tabular}

\section{Sample preparation to determine glyphosate}

A simple and easy procedure was used to extract glyphosate from the plant samples. The protocol is based on the QuPPE2 method (quick polar pesticides method) developed by the European Reference Laboratory of Single Residue Methods (EURL-SRM) and described as follows. In a $50 \mathrm{~mL}$ Teflon centrifuge tube, $2 \pm 0.02 \mathrm{~g}$ weed tissues was weighed and 10 $\mathrm{mL}$ water was added. The mixture was shaken by hand for $1 \mathrm{~min}$ to create slurry. Then, $10 \mathrm{~mL} \mathrm{MeOH} 1 \% \mathrm{HCOOH}$ was added and the mixture was shaken by hand for $1 \mathrm{~min}$. The tube was capped and centrifuged at $4000 \mathrm{rpm}$ for $5 \mathrm{~min}$. An aliquot of the extract was filtered through a $0.45 \mu \mathrm{m}$ syringe filter (cellulose) into a $2 \mathrm{~mL}$ autosampler vial (amber plastic), capped with a polytetrafluoroethylene (PTFE) cap, and placed in the freezer until injection.

\section{Determination of glyphosate by LC-MS/MS}

Glyphosate was determined using a combination of liquid chromatography (LC) and mass spectrometry (MS). An LC system was equipped with two pumps (ProStar 210; Varian, Palo Alto, California, USA) and an automatic sampler (ProStar 420) that was coupled with an electrospray ionization (ESI) source working in the positive mode and a triple quadrupole mass spectrometer (1200L, Varian) in the multiple reaction monitoring (MRM) mode. The transitions $170>$ 60 and $170>88$ were used for glyphosate. Separation was performed with a Hypercarb (P/N 35005-102130) column (100 $\mathrm{mm} \times 2.1 \mathrm{~mm} \times 5 \mu \mathrm{m}$ ), and the column temperature was $40{ }^{\circ} \mathrm{C}$. The elution solvents were solvent $\mathrm{A} \mathrm{as}_{2} \mathrm{O}, 1 \% \mathrm{HCOOH}$ and solvent $\mathrm{B}$ as $\mathrm{MeOH} 1 \% \mathrm{HCOOH}$. A gradient program was used that initially consisted of $100 \%$ solvent A held for 4 min (flow rate: $0.2 \mathrm{~mL} \mathrm{~min}^{-1}$ ), and linearly ramped over $4 \mathrm{~min}$ to $90 \%$ solvent $\mathrm{B}$. This composition was held for an additional 7 min before returning to the initial condition (flow rate: $0.4 \mathrm{~mL} \mathrm{~min}^{-1}$ ). The column was re-equilibrated for 5 $\mathrm{min}$ at the initial mobile phase composition. Total runtime was $20 \mathrm{~min}$ and the injection volume was $10 \mu \mathrm{L}$. Before each injection, the autosampler was washed with a methanol:water (50:50) solution to prevent carry-over.

\section{Sample preparation to determine triclopyr}

Sample preparation was performed according to the description by Anagnostopoulos et al. (2012). In a $50 \mathrm{~mL}$ Teflon centrifuge tube, an aliquot of $10 \pm 0.1 \mathrm{~g}$ weed tissues was weighed and $10 \mathrm{~mL}$ cold water $\left(<4{ }^{\circ} \mathrm{C}\right.$ to compensate heat increase caused by adding salts) was added. The mixture was shaken by hand for $1 \mathrm{~min}$ to create slurry. Then, $10 \mathrm{~mL}$ acetonitrile was added and the mixture was shaken again by hand for $1 \mathrm{~min}$. A mixture of the following salts was added: $4 \mathrm{~g} \pm 0.2 \mathrm{~g}$ anhydrous magnesium sulphate, $1 \mathrm{~g} \pm 0.05 \mathrm{~g}$ sodium chloride, $1 \mathrm{~g} \pm 0.05 \mathrm{~g}$ trisodium citrate dihydrate, and $0.5 \mathrm{~g} \pm 0.03 \mathrm{~g}$ disodium hydrogen citrate sesquihydrate. The tubes were immediately shaken by hand for $1 \mathrm{~min}$ and centrifuged for $5 \mathrm{~min}$ at $4000 \mathrm{rpm}$. An aliquot of the extract was filtered through a $0.45 \mu \mathrm{m}$ syringe filter (PTFE) into a 2 $\mathrm{mL}$ autosampler vial and placed in the freezer until injection.

\section{Determination of triclopyr with LC-MS/MS}

Triclopyr was determined with a Varian LC system equipped with two pumps (ProStar 210) and an automatic sampler (ProStar 420) that was coupled with an electrospray ionization (ESI) source working in the negative mode and a triple quadrupole mass spectrometer (1200L, Varian) in the multiple reaction monitoring (MRM) mode. The transitions $256>$ $220,256>198$, and $254>196$ were used for triclopyr. Analytes were separated with an Atlantis $\mathrm{C}_{18}$ column $(150 \mathrm{~mm} \times$ $2.1 \mathrm{~mm} \times 3.5 \mu \mathrm{m}$ ), and the column temperature was $25 \pm 4{ }^{\circ} \mathrm{C}$. The elution solvents were solvent A as acetonitrile: $\mathrm{H}_{2} \mathrm{O}$ (10:90), $1 \mathrm{mM} \mathrm{HCOONH}_{4}$, and $0.5 \% \mathrm{HCOOH}$ and elution solvent $\mathrm{B}$ was acetonitrile: $\mathrm{H}_{2} \mathrm{O}$ (90:10), $1 \mathrm{mM} \mathrm{HCOONH}_{4}$, $0.5 \% \mathrm{HCOOH}$. A gradient program was used that initially consisted of $80 \%$ solvent A and $20 \%$ solvent B and ramped linearly over the course of $8 \mathrm{~min}$ to $95 \%$ solvent $\mathrm{B}$. This composition was held for an additional $7 \mathrm{~min}$ before returning 
to the initial condition. The column was re-equilibrated for $10 \mathrm{~min}$ at the initial mobile phase composition. The flow rate was stable at $0.2 \mathrm{~mL} \mathrm{~min}^{-1}$ and total runtime was $25 \mathrm{~min}$. The injection volume was $5 \mu \mathrm{L}$ and the autosampler was purged with a mixture of methanol:water $(50: 50 \mathrm{v} / \mathrm{v})$ before sample injection to prevent carry-over.

\section{Identification and quantification procedure}

For both methods, quality control samples were performed to ensure validity of the results. Analytes were identified according to EU guidelines (European Commission, 2017) using retention times (RT) and ion ratio. The presence of an analyte in the sample was identified by the presence of a chromatographic peak at the time close to the RT of the reference standard $( \pm 0.1 \mathrm{~min})$ and the ratio of the two ion transitions should not deviate by more than $30 \%$ compared with the reference standard.

The analyte concentration $\left(\mathrm{mg} \mathrm{kg}^{-1}\right)$ in the sample was performed using single point calibration or bracketing. When using single point calibration, the surface area of the chromatographic peak of the sample is compared with the surface of the chromatographic peak of the reference standard when the surfaces of the sample peaks and standard solution do not differ by more than $50 \%$. When using bracketing, a comparison is made using two reference standards. The analyte concentration in the sample should be between the concentrations of the standards.

\section{RESULTS AND DISCUSSION}

The sample residue analysis identified significant differences in the glyphosate concentration. The presence of glyphosate in the sample was recognized by the presence of the chromatographic peak over time near the RT of the reference standard $( \pm 0.1 \mathrm{~min}$ ) (Figure 1). The highest concentration of glyphosate was detected in samples 10 and 9 , while both compounds were determined at lower concentrations in samples 3 and 4 (Table 2). In accordance with González-Torralva et al. (2012),

Figure 1. Chromatograms of sample 9 (Conyza canadensis) for the glyphosate transitions $(170>60,170>88)$.

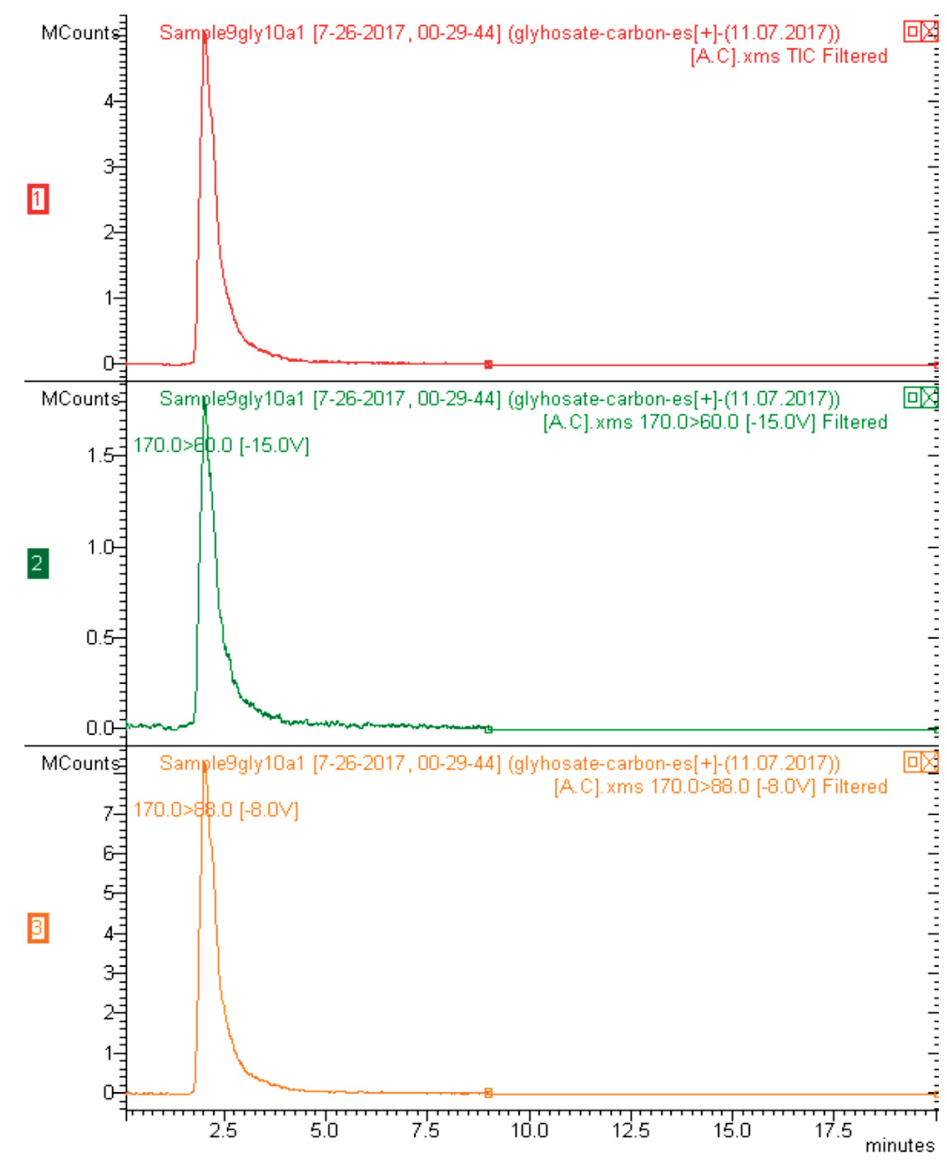


Table 2. Concentration of glyphosate residues found in samples 3, 4, 9, and 10 .

\begin{tabular}{lclc}
\hline Code & Biotypes & Findings & $\mathrm{mg} \mathrm{kg}^{-1}$ \\
\hline Sample 3 & Conyza bonariensis & Glyphosate & 21.39 \\
Sample 4 & C. bonariensis & Glyphosate & 22.03 \\
Sample 9 & C. canadensis & Glyphosate & 43.52 \\
Sample 10 & C. canadensis & Glyphosate & 44.57 \\
\hline
\end{tabular}

the resistant biotype has a stronger and faster metabolism than the sensitive biotype, transforming glyphosate into the aminomethylphosphonic acid (AMPA), glyoxylate, and sarcosine metabolites, thus reducing the amount of intracellular glyphosate that reaches the target enzyme EPSPS. The non-target-site-based mechanisms have been reported most frequently in glyphosate-resistant $C$. canadensis and C. bonariensis weed biotypes (Powles and Preston, 2006). Based on the results, samples 3 and 4 of $C$. bonariensis were potentially resistant to the herbicide glyphosate, whereas samples 9 and 10 (C.canadensis) were potentially susceptible to glyphosate; our findings completely concur with previous studies (Travlos et al., 2009; Travlos and Chachalis, 2010; 2013). These results indicated that $C$. bonariensis biotypes have a stronger metabolism than $C$. canadensis biotypes, transforming glyphosate into non-toxic metabolites. Based on some reports (Dinelli et al., 2006; Shrestha et al., 2007; VanGessel et al., 2009), C. canadensis is more susceptible at the rosette stage than at later growth stages.

Glyphosate degradation and transformation have been examined in previous studies as potential glyphosate resistance mechanisms (Lorraine-Colwill et al., 2002; Feng et al., 2004; Dinelli et al., 2006). Glyphosate is enzymatically metabolized to other nontoxic compounds such as glyoxylate, sarcosine, and formaldehyde (Rueppel et al., 1977), and a mildly toxic compound, AMPA. Our results confirm the involvement of glyphosate metabolism in the resistant biotype. Glyphosate-resistant Digitaria insularis biotypes have shown their ability to degrade glyphosate into AMPA, glyoxylate, and sarcosine. Furthermore, other authors working with glyphosate-tolerant plants (e.g., Ipomoea purpurea, Convolvulus arvensis, and Neonotonia wightii) have demonstrated the ability of these plants to metabolize glyphosate into AMPA, sarcosine, and glycine (Sprankle et al., 1978; Sandberg et al., 1980; Cruz-Hipolito et al., 2011).

Our results also revealed significantly different concentrations of triclopyr. The presence of triclopyr in the sample was recognized by the presence of the chromatographic peak over time near the RT of the reference standard $( \pm 0.1 \mathrm{~min})$ (Figure 2). The highest concentration of triclopyr was detected in samples 10 and 9 , while both analytes were determined at lower concentrations in samples 2, 3, 4, and 7 (Table 3). Non-target-site resistance involves mechanisms that minimize the amount of active herbicide reaching the target site (Yu and Powles, 2014). Specifically, non-target-site resistance mechanisms to the synthetic auxin herbicides, such as triclopyr, have frequently been associated with their metabolism by enzymes into harmless products. The major route for deactivating the endogenous auxin, indole-3-acetic acid (IAA), is by conjugation. The enzymes responsible for conjugating IAA can be considered as candidates for deactivating synthetic auxin herbicides and a potential source for resistance (Busi et al., 2018). Despite the frequent and repeated use of auxin herbicides, there are few reports of auxin herbicide-resistant weed biotypes that have been selected for use under these conditions that appear to be ideal for the evolution of resistance (Mithila et al., 2011). Based on the results, samples 2,3, and 4 (C. bonariensis) and sample 7 (C. albida) were less susceptible to the herbicide triclopyr, whereas samples 9 and 10 (C. canadensis) were susceptible to triclopyr.

Table 3. Concentration of glyphosate residues found in samples 2, 3, 4, 9, and 10.

\begin{tabular}{lcll}
\hline Code & Biotypes & Findings & $\mathrm{mg} \mathrm{kg}^{-1}$ \\
\hline Sample 2 & Conyza bonariensis & Triclopyr & 14.00 \\
Sample 3 & C. bonariensis & Triclopyr & 29.70 \\
Sample 4 & C. bonariensis & Triclopyr & 16.30 \\
Sample 7 & C. albida & Triclopyr & 22.00 \\
Sample 9 & C. canadensis & Triclopyr & 75.90 \\
Sample 10 & C. canadensis & Triclopyr & 44.00 \\
\hline
\end{tabular}


Figure 2. Chromatograms of sample 3 (Conyza bonariensis) for the three triclopyr transitions $(256>220,256>$ 198, $254>196$ ).

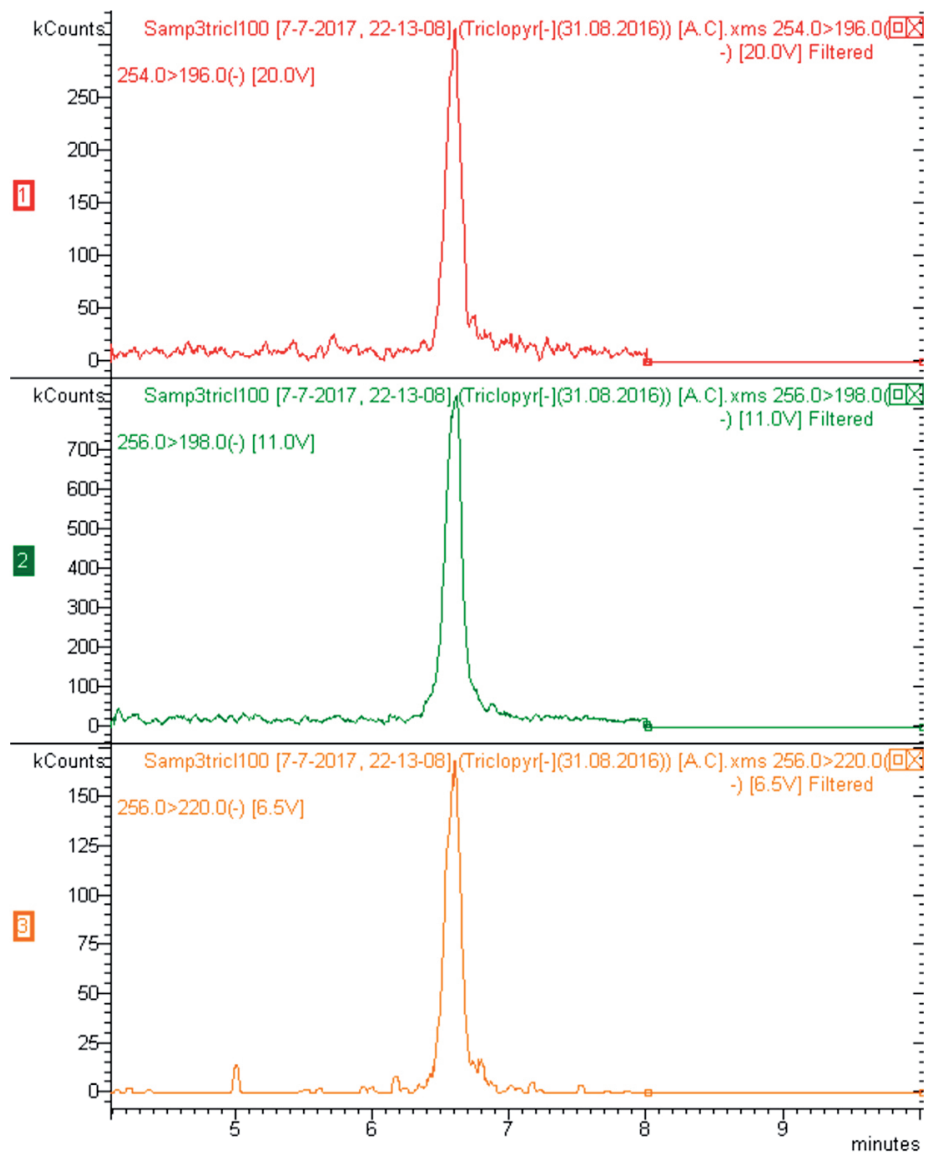

CONCLUSIONS

To date, available information is limited in the published literature on the role of the metabolism of glyphosate associated with glyphosate resistance in Conyza spp. This study is probably among the first to examine the response of three different species of Conyza to the herbicides glyphosate and triclopyr with complex analytical techniques (LC-MS/MS). As such, this study provides some potentially useful information for the quick and accurate biotype screening of the three Conyza species. Conyza spp. seem to have developed resistant biotypes in glyphosate and this resistance means that there are now fewer herbicidal control agents. Furthermore, Conyza spp. biotypes have been recorded as resistant to synthetic auxin herbicides. To determine the range of the resistant biotypes and better understand the biology and ecology of resistant and susceptible biotypes is essential for developing effective long-term integrated management strategies.

\section{REFERENCES}

Ahrens, W.H. 1994. Herbicide handbook. Weed Science Society of America, Champaign, Illinois, USA.

Anagnostopoulos, C.J., Liapis, K., Haroutounian, S., and Paspatis, E. 2012. Simultaneous determination of different classes of plant growth regulator in high water content agricultural products by liquid chromatography tandem mass spectrometry and time of flight mass spectrometry. Journal of Liquid Chromatography and Related Technologies 36:315-335.

Bradshaw, L.D., Padgette, S.R., Kimball, S.L., and Wells, B.H. 1997. Perspectives on glyphosate resistance. Weed Technology 11:189-198.

Busi, R., Goggin, D.E., Heap, I.M., Horak, M.J., Jugulam, M., Masters, R.A., et al. 2018. Weed resistance to synthetic auxin herbicides. Pest Management Science 74(10):2265-2276. 
Busi, R., Vila-Aiub, M.M., and Powles, S.B. 2011. Genetic control of a cytochrome P450 metabolism-based herbicide resistance mechanism in Lolium rigidum. Heredity 106:817-24.

Cruz-Hipolito, H., Rojano-Delgado, A., Domínguez-Valenzuela, J.A., Heredia, A., Luque de Castro, M.D., and De Prado R. 2011. Glyphosate tolerance by Clitoria ternatea and Neonotonia wightii plants involves differential absorption and translocation of the herbicide. Plant and Soil 347:221-230.

De Prado, J.L., Osuna, M.D., Heredia, A., and De Prado, R. 2005. Lolium rigidum, a pool of resistance mechanisms to ACCase inhibitor herbicides. Journal of Agricultural and Food Chemistry 53:2185-2191.

Dill, G.M. 2005. Glyphosate-resistant crops: history, status and future. Pest Management Science 61:219-224.

Dinelli, G., Marotti, I., Bonetti, A., Minelli, M., Catizone, P., and Barnes, J. 2006. Physiological and molecular insight on the mechanisms of resistance to glyphosate in Conyza canadensis (L.) Cronq. biotypes. Pesticide Biochemistry and Physiology 86:30-41.

European Commission. 2017. Guidance document on analytical quality control and method validation procedures for pesticide residues and analysis in food and feed. SANTE/11813/2017. 21-22 November 2017. European Commission, Directorate General for Health and Food Safety, Brussel, Belgium.

Feng, P.C.C., Tran, M., Chiu, T., Sammons, R.D., Heck, G.R., and CaJacob, C.A. 2004. Investigations into glyphosate-resistant horseweed (Conyza canadensis): retention, uptake, translocation, and metabolism. Weed Science 52:498-505.

Gaines, T.A., Zhang, W., Wang, D., Bukun, B., Chisholm, S.T., Shaner, D.L., et al. 2010. Gene amplification confers glyphosate resistance in Amaranthus palmeri. Proceedings of the National Academy of Sciences of the United States of America 107:1029-1034.

Ge, X., André d'Avignon, D., Ackerman, J.J.H., and Sammons, R.D. 2010. Rapid vacuolar sequestration: the horseweed glyphosate resistance mechanism. Pest Management Science 66:345-348.

González-Torralva, F., Rojano-Delgado, A.M., Luque de Castro, M.D., Mülleder, N., and De Prado, R. 2012. Two non-target mechanisms are involved in glyphosate-resistant horseweed (Conyza canadensis L. Cronq.) biotypes. Journal of Plant Physiology 169(17):1673-1679.

Hao, J.H., Qiang, S., Liu Q.Q., and Cao, F. 2009. Reproductive traits associated with invasiveness in Conyza sumatrensis. Journal of Systematics and Evolution 47:245-254.

Heap, I. 2019. The international survey of herbicide resistant weeds. Online. Internet. Available at www.weedscience.com (accessed May 2019).

Holm, L.G., Doll, J., Holm, E., Pancho, J.V., and Herberger J.P. 1997. World weeds, natural histories and distribution. Wiley, Hoboken, New Jersey, USA.

Lewer, P., and Owen, W.J. 1987. Uptake and metabolism of triclopyr by soybean cell suspension cultures: a comparison with 2,4-dichlorophenoxyacetic acid. Transactions of the Biochemical Society 15(6):1107-1108.

Lorraine-Colwill, D.F., Powles, S.B., Hawkes, T.R., Hollinshead, P.H., Warner, S.A.J., and Preston, C. 2002. Investigations into the mechanism of glyphosate resistance in Lolium rigidum. Pesticide Biochemistry and Physiology 74:62-72.

Mithila, J., Hall, J.C., Johnson, W.G., Kelley, K.B., and Riechers, D.E. 2011. Evolution of resistance to auxinic herbicides: historical perspectives, mechanisms of resistance, and implications for broadleaf weed management in agronomic crops. Weed Science 59:445-457.

Nandula, V.K., Reddy, K.N., Rimando, A.M., Duke, S.O., and Poston, D.H. 2007. Glyphosate- resistant and susceptible soybean (Glycine max) and canola (Brassica napus) dose-response and metabolism relationships with glyphosate. Journal of Agricultural and Food Chemistry 55:3540-3545.

Neve, P., Diggle, A.J., Smith, F.P., and Powles, S.B. 2003. Simulating evolution of glyphosate resistance in Lolium rigidum II: past, present and future glyphosate use in Australia cropping. Weed Research 43:418-427.

Newton, M., Roberts, F., Allen, A., Kelpsas, B., White, D., and Boyd, P. 1990. Deposition and dissipation of three herbicides in foliage, litter and soil of brush fields of Southwest Oregon. Journal of Agricultural and Food Chemistry 38(2):574-583.

Owen, M.D.K., and Zelaya, I.A. 2005. Herbicide-resistant crops and weed resistance to herbicides. Pest Management Science 61:301-311.

Powles, S.B. 2008. Evolved glyphosate-resistant weeds around the world: lessons to be learnt. Pest Management Science 64:360-365.

Powles, S.B., and Preston, C. 2006. Evolved glyphosate resistance in plants: biochemical and genetic basis of resistance. Weed Technology 20:282-289.

Powles, S.B., and Yu, Q. 2010. Evolution in action: plants resistant to herbicides. Annual Review of Plant Biology 61:317-347.

Radosevich, D., and Bayer, F. 1979. Triclopyr silvicultural herbicide. Weed Science 27:1-22.

Rueppel, M.L., Brightwell, B.B., Schaefer, J., and Marvel, J. 1977. Metabolism and degradation of glyphosate in soil and water. Journal of Agricultural and Food Chemistry 25:517-528.

Sandberg, C.L., Meggitt, W.F., and Penner, D. 1980. Absorption, translocation and metabolism of ${ }^{14}$ C-glyphosate in several weeds species. Weed Research 20:195-200.

Shrestha, A., Hembree, K.J., and Va, N. 2007. Growth stage influences level of resistance in glyphosate-resistant horseweed. California Agriculture 61:67-70. 
Sprankle, P., Sandberg, C.L., Meggitt, W.F., and Penner, D. 1978. Separation of glyphosate and possible metabolites by thinlayer chromatography. Weed Science 26:673-674.

Travlos, I.S., and Chachalis, D. 2010. Glyphosate-resistant hairy fleabane (Conyza bonariensis) is reported in Greece. Weed Technology 24:569-573.

Travlos, I.S., and Chachalis D. 2013. Relative competitiveness of glyphosate-resistant and glyphosate susceptible populations of hairy fleabane, Conyza bonariensis. Journal of Pest Science 86:345-351.

Travlos, I.S., Chachalis, D., and Economou, G. 2009. Characters for the in situ recognition of some Conyza species and glyphosate resistant populations from Greece. p. 63. In Rubin, B., and Economou, G. (eds.) Proceedings of the $2^{\text {nd }}$ International Conference on Novel and Sustainable Weed Management in Arid and Semi-Arid Agro-Ecosystems, Santorini. 7-10 September. Agricultural University of Athens, Athens, Greece.

Urbano, J.M., Borrego, A., Torres, V., Leon, J.M., Jimenez, C., Dinelli, G., and Barnes, J. 2007. Glyphosate-resistant hairy fleabane (Conyza bonariensis) in Spain. Weed Technology 21:396-401.

VanGessel, M.J., Scott, B.A., Johnson, Q.R., and White-Hansen, S.E. 2009. Influence of glyphosate-resistant horseweed (Conyza canadensis) growth stage on response to glyphosate applications. Weed Technology 23:49-53.

Yu, Q., Huang, S., and Powles, S. 2010. Direct measurement of paraquat in leaf protoplasts indicates vacuolar paraquat sequestration as a resistance mechanism in Lolium rigidum. Pesticide Biochemistry and Physiology 98:104-109.

Yu, Q., and Powles, S. 2014. Metabolism-based herbicide resistance and cross-resistance in crop weeds: a threat to herbicide sustainability and global crop production. Plant Physiology 166(3):1106-1118. 